\title{
Management and transformation of urban spaces in San Juan de Puerto Rico during the government of Miguel de la Torre (1823-1837)
}

\author{
Emilio José Luque Azcona \\ Universidad de Sevilla, Facultad de Geografía e Historia. \\ e-mail: eluque1@us.es \\ ORCID iD: https://orcid.org/0000-0002-0588-4891
}

Submitted: 3 November 2019. Accepted: 27 May 2020

\begin{abstract}
This article analyses aspects related to the development of the paving, lighting, sewerage and cleaning of streets and squares in the city of San Juan de Puerto Rico, during Miguel de la Torre's government of the island (1823-1837). With this research we intend to offer a new and complementary view to the existing one on the management of this governor, who, along with the Cabildo, had powers in these matters, while at the same time deepening the analysis of the urban history of the city of San Juan for that period. The information on the experience that other relevant urban centers of the period, such as Madrid, Mexico or Havana, had in this type of actions is also included, with the purpose of contextualizing both the measures applied and their scope.
\end{abstract}

KEYWORDS: Urban History; Urban police; Paving; Lighting; San Juan de Puerto Rico; Miguel de la Torre.

Citation / Cómo citar este artículo: Luque Azcona, Emilio José (2020) "Management and transformation of urban spaces in San Juan de Puerto Rico during the government of Miguel de la Torre (1823-1837)" Culture \& History Digital Journal, 9 (2): e021. https://doi.org/10.3989/chdj.2020.021

RESUMEN: Gestión y transformación de los espacios urbanos de San Juan de Puerto Rico durante el gobierno de Miguel de la Torre (1823-1837).- Este artículo analiza aspectos relacionados con la evolución del empedrado, alumbrado, alcantarillado y limpieza de sus calles y plazas de la ciudad de San Juan de Puerto Rico, durante el gobierno en la isla de Miguel de la Torre (1823-1837). Con esta investigación pretendemos aportar una nueva mirada y complementaria a la existente sobre la gestión de este gobernador, que junto al Cabildo tenía atribuciones en estas materias, al tiempo que profundizar en el análisis de la historia urbana de la ciudad de San Juan para ese período. También, con el objetivo de contextualizar las medidas aplicadas y el alcance que tuvieron, se incluyen informaciones sobre la experiencia que otros centros urbanos relevantes del período, como Madrid, México o La Habana, tuvieron en este tipo de actuaciones.

PALABRAS CLAVE: Historia urbana; Policía urbana; Empedrado; Alumbrado; San Juan de Puerto Rico; Miguel de la Torre.

Copyright: (C) 2020 CSIC. This is an open-access article distributed under the terms of the Creative Commons Attribution 4.0 International (CC BY 4.0) License. 


\section{INTRODUCTION}

After constituting a peripheral space in the context of the Spanish Empire in the Americas, Puerto Rico became, together with Cuba, one of the last Spanish possessions and outposts in the Americas. This situation contributed to the emergence of an interest in "protecting, maintaining and developing the island of Puerto Rico as a bastion of the monarchy", within the setting of a declining empire (Altieri, 2007, p. 34). As a result, cities such as Havana and San Juan were among the Latin American urban centers where prosperity and change were most evident during this period, as opposed to the stagnation and disorder experienced in most of the settlements of the independent regions of Spain. The only exceptions to this are some port cities, which generally became new national capitals, such as Buenos Aires, Montevideo and Panama (Romero, 1986, p. 250).

This vision contrasts with Puerto Rico's traditional history of the island's management by military officials during the 19th century, which was seen as militaristic, ultraconservative and therefore against progress. All this, especially for governments such as that of Miguel de la Torre -developed between 1823 and the beginning of 1837- that is undervalued and not greatly studied to date. Accordingly, Historian José Luis Vivas Maldonado, in his Historia de Puerto Rico (History of Puerto Rico) published in the 1970s, included the period of his government in a chapter entitled De los pequeños Césares (Of the Little Caesars), calling it one of the "darkest" moments in the island's history. Among the aspects he highlighted are his Decretos or Bandos (Decrees or Edicts) with which he regulated even the smallest details of citizens' lives, and the fact that various historians referred to his government as el de las tres Bes: baile, bebida y bara$j a$ (that of the three B's - dancing, drinks and cards), because of De la Torre's own belief that "People who have fun, do not conspire" (Vivas Maldonado, 1974, pp. 193197). Ten years later, Jesús Lalinde Abadía, in his book on La administración española en Puerto Rico durante el siglo XIX (Spanish administration in Puerto Rico during the 19th century), included this ruler, one of the greatest exponents of absolutism, among the Captains General who have left a negative impact, in his case for re-establishing the "omnimodas" (extraordinary powers that assisted him in his government as commander of the besieged city) and for having established the aforementioned government of the three B's (Lalinde Abadía, 1980, p. 136).

More recent works have focused on the study of Miguel de la Torre's government, concentrating also on the study of the mechanisms used during his administration for the ideological control of the island's inhabitants, with the purpose of "distancing them from segregationist intentions". Among them are some works published by Historian Jesús Raúl Navarro García in which he refers to matters related primarily to the island's administration and ideological control (Navarro García, 1991, p. 11) (Navarro García, 1999, pp. 91-156). Another author, Car- los D. Altagracia Espada, analyses the period from a similar viewpoint, concluding how the articulation of power relations, by means of a disciplinary system in the framework of the Age of Independence Revolutions in Latin America, represented for Puerto Rico "the re-articulation and strengthening of the practices of the Spanish government" (Altagracia Espada, 2013, p. 105).

In addition to these works, we must mention two doctoral theses that have also shown interest in the analysis of this period of Puerto Rican history, proposing -in both instances- a new examination of De la Torre's administration, analyzing it in a broader context than that of the island. We are referring to the one by Nelson Hernández on La política económica de Miguel de la Torre (The Economic Policy of Miguel de la Torre), 1823-1837, directed by Dr. Gervasio García and defended at the University of Puerto Rico in 1987. Also, the one by María Providencia Ortiz Malave, under the direction of Dr. Marcial E. Ocasio, on El estado español y su proyecto de modernización del siglo XIX: infraestructura vial en la isla de Puerto Rico durante la gobernación de Miguel de la Torre (18221837) [The Spanish State and its 19th Century Modernization Project: Road Infrastructure on the Island of Puerto Rico during the Governorate of Miguel de la Torre (18221837)], defended at the Centro de Estudios Avanzados de Puerto Rico y el Caribe (Center for Advanced Studies on Puerto Rico and the Caribbean) in 2016. The latter proposes a new vision of the Spanish State on the island for that period, considering it as a promoter of "modernizing reforms in spite of the conservative nature of its institutions", concerning the improvement of communications through the building of roads (Ortiz Malave, 2016, pp. 3 and 8).

In accordance with María Providencia's ideas on road infrastructure, in this article we have set out to study the transformations undergone by the city of San Juan in the urban planning field during the period of Miguel de la Torre's government on the island, focusing on aspects related to the development of paving, lighting, sewerage and the cleaning of its streets and squares. Our aim is to provide a new and complementary view to the existing one on this governor's management of the island, who, together with the Cabildo (Town Council), had powers in these matters. We also seek to deepen the knowledge of some aspects related to the urban administration of San Juan during the first half of the 19th century, for which some authors such as Adolfo Hostos (1948 and 1957), María de los Ángeles Castro (1980 and 1984), Aníbal Sepúlveda (1989) or María Teresa Cortés Zabala (20092010 and 2017) have made important and outstanding contributions. Indeed, the third of them, in his book San Juan, Historia ilustrada de su desarrollo urbano, 15081898 (San Juan, History of its Urban Development, 15081898), highlighted the "scarce, irregular and biased" knowledge available about San Juan's urban development and planning history ${ }^{1}$ (Sepúlveda Rivera, 1989, p. 2).

With this study we want to verify to what extent, during Miguel de la Torre's government and in parallel with the most important aspects of his term of office -related to 
the island's administration and ideological control- there were notable advances in the paving, lighting, sewerage and cleaning of streets and squares in the city of San Juan. To this end, the main sources used have been the Actas de Cabildo (Town Council Minutes) of the city of San Juan for the period between 1823 and January 1837, which are in the Archivo General de Puerto Rico (General Archives of Puerto Rico), as well as what has been contributed by other authors on this subject through an analysis by the Bandos de Policia y Buen Gobierno. Likewise, in order to determine to what extent the events in San Juan were in line with those in cities where the island maintained administrative and/or economic ties, we have included references to the cases of Madrid, Mexico and Havana.

\section{ENLIGHTENMENT AND URBAN PLANNING}

Spain was among the European regions in which, together with the general reforms of the organization of the State, urban planning achievements were most extensive throughout the 18th century (Sica, 1982, pp. 125 and 157). Then a new concept of city appeared, which had to be contextualized in a global reform project of the Spanish society under the Bourbon reign, and which intended to promote wealth by the intensive exploitation of natural resources and the increase of internal and external trade. To achieve this, it was indispensable to carry out a significant public works program to improve communications and effectively colonize strategic areas (Solano, 1988, p. 37).

Similarly, in order for public institutions to achieve greater control over city spaces and dwellers, attempts were also made to identify the main ills that afflicted them, their economic availability and to determine their most noteworthy characteristics (Anguita Cantero, 1997, pp. 112-114). As a consequence, Police science, understood as an overall concept of the city and its government, generated a set of rules and experiences that included many different aspects, some of them of a more general nature, such as good habits, and others of a more particular nature related to hygiene, such as the paving of streets or the siting and functioning of markets. Their implementation sought to establish rules and forms of government applicable to all inhabitants, promoting the public good on behalf of the King (Gortari Rabiela, pp. 117 and 120).

It is important to highlight the development of a branch of medico-social knowledge, during the second half of the 18th century, which took an interest in the human organism and in the appropriate design and management of urban spaces. Its main objective was to eradicate disease focal points and to control water and air circulation processes, "which were seen as two of the main vehicles for the spread of the most deadly diseases". In this sense, moving cemeteries to the urban periphery, increasing free open spaces, building Hospitals, Hospices and Prisons and supplying and evacuating water were some of the main measures promoted (Jori, 2013).

To achieve all this, the Bourbons did not hesitate in employing qualified professionals to apply the above- mentioned series of measures. As a consequence, some improvements were made to the urban infrastructures of the main cities in peninsular Spain during the last decades of the 18th century and the first decades of the 19th century. All this resulted in the development of initiatives aimed at the paving and lighting of streets and squares and the construction of boulevards and avenues, highlighting, in this regard, examples such as the Paseo del Prado in Madrid (Reguera Rodríguez, 1992, p. 121) (Jiménez Garnica, 2002, pp. 171 and 175). There was also the division of urban centers into barracks and neighborhoods with mayors in charge of maintaining public order, inspecting, monitoring and controlling everything that happened in their respective neighborhoods, a measure that came into effect in 1768 in the case of Madrid. Moreover, the Bandos de Buen Gobierno acquired great relevance during the second half of the 18 th century, as a legal instrument for city government and an ordinary means of communication with subjects (Reguera Rodríguez, 1992, p. 122), (Escobedo Mansilla, 1995, pp. 473495).

In American and Caribbean urban settings, policies aimed at promoting economic development, defending territory, controlling population and eradicating violence were similarly expressed. Although a reformist approach was present in the region from the beginning of the century, it was the English takeover of Havana and Manila in 1762 that triggered the implementation of the reform program. Thus, after the recovery of the first one, a politicalterritorial reorganization started to be applied that resulted in a system of intendencias (Quartermasters), initially creating the Intendencia General del Ejército y Hacienda of the Island of Cuba in 1764, that of Louisiana in 1775 and Venezuela in 1776. In 1782 the Ordenanza de Intendentes (Ordinance of Intendants) was promulgated, which was to be applied in the Rio de la Plata and which in 1784-1786 was also extended to Peru, New Spain and Chile. With this measure, a new hierarchy of power was established and the importance of the cities that were chosen as Quartermaster capitals was ratified, a fact that allowed them, among other things, to experience a deep urban renewal. Consequently, the intendants had a leading role, together with the viceroys, in providing infrastructure and equipment to their respective cities, confronting Cabildos, which were suspicious of their interference in matters that, until then, had been their responsibility (Vega Janino, 1989, pp. 240-243). With them, a significant number of provisions referring to the urban planning, supply, cleanliness and order in urban centers were also elaborated by other authorities, such as governors, hearings and president-governors.

Focusing on measures aimed at the paving, cleaning and lighting of streets and squares, during the second half of the 18th century efforts were made in different cities of peninsular Spain and Hispanic America with limited results, depending on the case, until the mid-19th century. As far as pavement is concerned, in 1761 , under the reign of Charles III, the "Instructions for the new pavement and cleaning of the streets of Madrid, in which Don Francisco 
Sabatini's Project is substantially contained" was issued, with which the Italian architect planned to pave the Carrera de San Jerónimo in an experimental way, with quartzite pebbles on one side and with granite slabs on the other. For authors like David Martín Freire-Lista, this is one of "the first durability and quality tests for construction materials in Spain" (Freire-Lista, 2016, p. 30). Seven years later, all the streets of the Villa had new paving, except for some where the homeowners said they could not afford to pay for it. In the following decades work mainly focused on the maintenance and repair of roads and sidewalks, as Madrid did not experience significant growth until the second half of the 19th century (Gili Ruiz, 2017, p. 443)

Thanks to the collaboration of several institutions, by 1776 Mexico City was also largely paved (Moncada Maya, 2006). However, in the following decades, the viceroys had to dictate new measures oriented towards the leveling of streets, the establishment of culverts and pavements for water stagnation, as well as the repair of water distribution and the opening of pathways and roadways (Hernández Franyuti, 1997, pp. 49-50). Accordingly, the promoters of this initiative generally encountered many difficulties, especially due to the neighborhood's opposition to payment obligations (Sánchez de Tagle, 1995, pp.149-154) (Sánchez de Tagle, 1997). This is also evident in the Instrucción reservada que el conde de Revilla Gigedo, dio a su sucesor en el mando, Marqués de Branciforte (Reserved Instructions that the Count of Revilla Gigedo gave to his successor in command, the Marquis de Branciforte), which includes a detailed account of all the bureaucratic and economic aspects that prevented the rapid progress of the paving work on the capital's streets. One of the problems was precisely the taxes approved for this cause by the aforementioned Viceroy, Juan Vicente de Güemes Pacheco, second Count of Revillagigedo (17891794), who did not receive the approval of the Crown, as was the case with the pulques. Others, such as the taxation of cars and houses, presented great difficulty for approval (Instrucción reservada..., 1831, pp. 65-71). In the case of Havana, there were also several factors that delayed the implementation of the first initiatives for the paving of streets and squares, which occurred during the government of the Marquis de la Torre in the 1770 s, and as a result it was not until the second third of the 19th century that a solid pavement was finally achieved with cobblestone (Apaolaza-Llorente, 2018, p. 74).

As for lighting, although public oil lamps were the first lighting service in the main urban centers during the 18 th and 19th centuries, gas lamps were already used on the streets of the most important cities in Europe in the early 18 th century, although their usage would not become widespread until the 1830s-1840s (Madrid Calzada, 2007, pp. 15 and 21). However, in the case of Madrid, different factors delayed the general use of gas until the middle of the century. Previously, only a few gas lights were found in the Plaza de Oriente, installed for the birth of the Infanta (Princess) Luisa Fernanda in 1832 (Arroyo, 2002, pp. 137-138). In Mexico, after the failure of the
Bandos approved in 1783 in this matter, the previously mentioned second Count of Revillagigedo inaugurated, in April 1790, about 1,128 lanterns "made of glass with tin plate lamps, with the wick fed by colza oil, held by lamps called pies de gallo" (rooster legs), which were reinforced in 1849 with 450 turpentine lamps (Contreras Padilla, 2014, pp. 47). Gas lighting would reach the first streets of the capital in 1869, thanks to the Compañia de Gas Hidrógeno Carbonado (Hydrogen Carbonate Gas Company), of English capital (García Lázaro, 2016). In Havana, the first significant advances in this area also occurred during the last decades of the 18th century, during the government of the Count of Santa Clara when power and functionality were improved by replacing fat with oil (Apaolaza-Llorente, 2018, p. 74). Later on, during the government of Miguel Tacón (1834-1838) and, as happened in Mexico, private capital was incorporated into the public lighting administration (Amigo Requejo, 2013, pp. 6 and 8). This city acquired a high technological profile in this area as a result of the installation of modern gas systems imported from the United States in 1846 (Amigo Requejo, 2014, pp. 16 and 24).

Some of the main drawbacks to cleaning up streets, squares and plots of land were, for cases such as Madrid, the existing economic difficulties, the poor social understanding of the established measures, the neighbors' reluctance to comply with the dumping schedule conditions, the little diligence of the Ayuntamientos (City Halls) and the lack of technical and human resources (Blanco Esquivias, 1998, p. 130). Aspects such as the construction of an efficient sewerage system were not fully resolved, in spite of the efforts made from the reign of Charles III until the late 19th century, with measures such as the construction of the Canal de Isabel II (Gili Ruiz, 2017, pp. 675-676).

In Mexico City, also during the government of the aforementioned second Count of Revillagigedo, city spaces truly became a major point in the viceroyalty's politics, an issue that would be reflected -together with the previously described progress made in paving worksin the renovation and opening of new avenues, the removal of dunghills and the organization of a waste collection system in carts (Hernández Franyuti, 1997, pp. 55 and 73), (Medel, 1992, p. 372). The scope of these actions, similar to what happened in Madrid, was quite limited, especially in the outskirts, both because of the nonobservance of the laws, as well as the bureaucratic problems that slowed down the processes and for being a practice that was misunderstood by the great majority (Rodríguez, 2000; Dávalos, 1989 and 1997). The first attempt to establish a garbage collection system in Havana occurred on similar dates, coinciding with the government of José Manuel de Ezpeleta (1785-1789). However, here again, as in the previous cases, results were limited, which is why it should be remembered years later, under the government of the Count of Santa Clara in the following decade, that the neighbours were responsible for taking garbage to the designated areas outside the city (Apaolaza-Llorente, 2018, pp. 70-72). 


\section{PUERTO RICO DURING THE GOVERNMENT OF MIGUEL DE LA TORRE}

Some of the events that took place in Puerto Rico and its main urban center, San Juan, in the first half of the 19th century would not have been possible without the major transformations that took place in the island's socioeconomic structure at the time. These changes were brought about by a series of measures adopted as a result of the abolition of the Mexican situado in 1810, forcing the island to develop its own economy, which was based mainly on the production and export of sugar, coffee and tobacco (González Vales and Luque, 2012, p. 13). Among these modifications are some, such as the promulgation of the Real Cédula de Gracias (Royal Decree of Graces) in 1815 and those adopted by Mayor Alejandro Ramírez for the institution of free and direct trade with Spain and other countries, the encouragement of local production and trade, the immigration of qualified and resourceful people and the introduction of a larger number of slaves $^{2}$ (Naranjo Orovio, 1992, pp. 298-299).

Different authors conclude that these new regulations could be, in fact, a legal adjustment to a situation that had been developing previously (Espinosa Fernández, 2015, p. 25). In this regard, Historian Jesús Raúl Navarro notes that, while the changes in the island's socioeconomic structure became more evident starting in the second decade of the 19th century -coinciding precisely with the government of Miguel de la Torre- "these new winds" had begun to arrive somewhat earlier, specifically in the context of the Bourbon reforms over the final decades of the 18th century (Navarro García, 1991, p. 17).

Nevertheless, the truth is that the ideas of the Enlightenment arrived in Puerto Rico with a certain delay in comparison with other territories of Hispanic America, and some precedents can be found in several measures developed by Captains General stationed on the island in the last decades of the 18th century (Castro, 1984, p. 22). Also, in the presence of other Crown representatives who, imbued with the ideas of the Enlightened Reform, made a whole series of proposals for the development and promotion of the island. These include some like Field Marshal Alejandro O'Reilly who, arriving in 1765 to assess military and defensive aspects, advised the Crown to enhance Puerto Rico's agricultural profile; or Benedictine monk Fray Íñigo Abbad y Lasierra, author of the work Historia geográfica, civil y natural de la Isla de San Juan Bautista de Puerto Rico (Geographic, civil and natural history of the island of Saint John the Baptist of Puerto Rico). Other enlightened figures stand out in the early 19th century, such as the first diputado a Cortes (member of the Spanish Parliament), Ramón Power y Giralt, or the previously mentioned intendant of the island, Alejandro Ramírez (Ortiz Malave, 2016, pp. 26-29). Furthermore, the presence of enlightened ideas can also be observed in the debates held by leading Church members, military officials, landowners, the Creole intellectual elite and local government representatives, in relation to land-use planning for production, workforce regulation, trade and edu- cation (Cortés Zavala, 2009-2010, pp. 110-111). For María de los Ángeles Castro, enlightened ideas reached their peak on the island precisely during the Miguel de la Torre government (Castro, 1984, p. 22).

Puerto Rico's regional context is also an important factor to take into account in order to understand some of the aspects that characterized the island during the first half of the nineteenth century. On the one hand, the events that took place in the French colony of Saint-Domingue beginning in 1789, with the outbreak of the first slave revolution in 1791, which culminated in the creation of an independent state, Haiti, in 1804. These events led to at least two consequences for Puerto Rico: an economic climate favourablee for the sugar produced in Puerto Rico to occupy part of the vacuum left by the former French colony, as well as the fear of a possible slave uprising on the part of the island's authorities. On the other hand, as from 1810, the independence revolutions in Latin America once again highlighted Puerto Rico as an important military post, causing it to "rearticulate and strengthen Spanish government practices". Against this background, in 1822, Miguel de la Torre arrived in Puerto Rico, after his defeat a year earlier in Carabobo by Simón Bolívar, taking office as the island's governor and Captain General from 1823 to January 1837, with the authority to govern the colony as a besieged plaza and contain the separatists' desires within it (Altagracia Espada, 2013, pp. 13-15). With the creation of the Real Audiencia of Puerto Rico (Royal Audience of Puerto Rico) by royal decree in 1831 and its establishment the following year, De la Torre would also assume the presidency of this body (Lalinde Abadía, 1980, pp. 138-147).

Regarding the island's infrastructure, it was also during Miguel de la Torre's administration that internal roads began to undergo major transformations, as a mechanism of social and military control and according to the agricultural stimulus and population growth experienced (Ortiz Malave, 2016, p. 4). Yet, regardless of the progress made in this area, the fact is that large areas of the island's interior would still remain largely isolated (González Vales and Luque, 2012, p. 147).

As far as urban areas are concerned, cabildos were one of the most active agents in terms of management, providing both human and financial resources for the works and actions carried out. In the case of Puerto Rico, there were two cabildos until the end of the eighteenth century, that of San Juan and that of Villa de San Germán, the first being somewhat older and having the "longest" jurisdiction, and the second covering the western part of the island. As Luis González Vales points out in his article El Cabildo de San Juan Bautista de Puerto Rico en el siglo XVIII y la defensa de los derechos de los vecinos (The Cabildo of San Juan Bautista of Puerto Rico in the 18th century and the defence of neighbours' rights), the management of the local government body responds entirely to the typification of the cabildo indiano by Abelardo Levaggi, in relation to the outstanding role played by "these corporations in local economic life" and regarding "the progress, mainly material, of the city”. (González Vales, 1990, p. 205). 
On this last point, and as far as public works in San Juan are concerned, the priority during the 18th century was to keep the islet communicated, thus the maintenance of the San Antonio and Martín Peña bridges was fundamental. Other aspects dealt with in this matter were the conservation of the ayuntamiento building and the streets -we shall refer to the latter in the following section- as well as taking care of works that met community needs, relating to butchery, slaughterhouses, water fountains, pig pens and the ranches that were used as sales stalls. In terms of public health and hygiene, one of the main concerns was to prevent the spread of diseases (Caro Costas, 1974, pp. 152-173). Consequently, over the first half of the nineteenth century, the cemetery was also relocated from its original site, from the south side of the cathedral to the north of the enclosure, in an area between the walls and the Atlantic Ocean. The blessing of the cemetery took place in May 1814 (Castro, 1980, p. 166; Sepúlveda Rivera, 1989, p. 298).

Municipal ordinances had to be supervised in Puerto Rico by the Real Audiencia of Santo Domingo and, eventually, approved by the Real y Supremo Consejo de Indias (Royal and Supreme Council of the Indies), with the governor's frequent intervention in the organization and operation of municipal councils (González Vales, 1990, p. 206). This event led to the Captains General taking an active role in the decisions that affected the development of the island's urban centers, not only through the matters handled by the cabildos, but also by regulating measures with the Bandos de Policia y Buen Gobierno. In this sense, Maria de los Angeles Castro, when analysing the aforementioned Bands for the Puerto Rican environment, distinguishes three types of regulations. The first one refers to the city' $\mathrm{s}$ organization and embellishment by means of the urban layout of streets, the regulation of constructions, and the remodeling and alignment of houses and buildings; the second one refers to the preservation and cleaning of streets, squares and avenues; and the third one has to do with the security of the city's inhabitants and the government's stability. She also mentions that the nineteenth-century Bandos were more explicit than the previous ones when referring to these aspects (Castro, 1984, pp. 15-16).

Concerning Miguel de la Torre's management role in these matters, there is no doubt that an abnormally extensive government like his, together with keeping a positive relationship with the Cabildo de San Juan -where he was president- had to continuously encourage the implementation of action plans and more evident results. Such an assumption could be supported, with due prudence, by testimonies of the time that highlight precisely the contribution that this Captain General made to the progress of the city of San Juan ${ }^{3}$. In this regard, María de los Ángeles Castro sees his administration as the beginning of the "most significant period in San Juan's development as a civil city", due to his direct participation in works such as those of the theatre and the conciliar seminary, as well as the initial shaping of the city "according to neoclassical physiognomy" during the first years of Isabel II's reign (Castro, 1980, p. 185).

We will now see how effective his management, together with that developed by the Cabildo, was in terms of paving, lighting and the cleaning of streets and squares.

\section{PAVING}

Aida R. Caro, in her book on El cabildo or régimen municipal puertorriqueño en el siglo XVIII, provides valuable information on this local body's management of public works. In this sense, she mentions how, at the end of that century, the city of San Juan had a total amount of thirteen streets: six that ran from East to West (Los Cuarteles or Tetuán, Santa Catalina, San Francisco, La Luna, Sol and San Sebastián) and seven that ran from North to South (La Tanca, San Justo, de la Cruz, San José, Santo Cristo, Caleta de Las Monjas and Caleta de San Juan). At that time, among the factors that contributed to their deteriorated state, the aforementioned author highlights both the torrential rains that fell between May and September, and the use of streets for transit and as a sewage dump. To avoid this situation, during the second half of the century, all the streets were repaired and specific arrangements were made for carrying out military manoeuvres, as required by the governor. Each year one of the regidores (aldermen), who acted as commissioner of streets and bridges, was responsible for supervising and reporting on the state and layout of new streets (Caro Costas, 1974, pp. 163-165).

In the mid-1770s, after the city was divided into four cuarteles, the council issued and implemented provisions for street signs and house numbering (Caro Costas, 1974, p. 165). As for the paving project, Friar Iñigo Abbad, in his description of the city in 1776, emphasized how all the streets were "unpaved: in some areas one can see the rock in the ground, in others quicksand that is hard to walk on" (Castro, 1980, p. 141). In order to alleviate this situation, during the government of Juan Andrés Dabán (1782-1789), they took action on the streets that most urgently needed it, determining -by an open cabildo in 1784- preference for those running from north to south. To this end, the corresponding means were approved, work began using river pebbles, lime, mud, sand and bricks, and they requested that the governor carry out the necessary repairs for their maintenance (Caro Costas, 1974, pp. 163-166). The hauling of materials for the fortification of the plaza was another factor that contributed to the poor condition of the streets at that time (Sepulveda Rivera, 1989, p. 124).

In spite of these measures, at the beginning of the 1820 s two-thirds of the town's streets were "unpaved", and many of them were unusable. At the Cabildo session held on July 1,1822 , it was stressed that paving would be beneficial to public health, among other benefits, and that it would prevent the port from being blocked by the dirt being washed away by the continuous rains ${ }^{4}$. During the 1820 's, the main roadwork was generally carried out on the eve of festivities, such as Corpus Christi or San Juan's 
Day, so as to avoid possible misfortunes during the planned events, although it was not unusual to request the use of prisoners from La Puntilla for this purpose and "for economy to work"s.

In July 1822 also, specifically at the session held on the 8th, the Alcalde $2^{\circ}$ (Second Mayor), in addition to paving the city streets, proposed the renovation of the Plaza Mayor, then known as the Plaza de la Constitución. With masonry seats, a greater number of lanterns for the lighting and the construction of a pyramid, the Plaza Mayor would be a place where the neighbourhoodd could relax in the hot afternoons and nights. An estimate for this would be requested from the Maestro Mayor de obras de fortificación (Master Builder of Fortification Works) and the city's master builder ${ }^{6}$.

The issue of street paving would be discussed again at the Cabildo on January 26, 1824, where they agreed to ask the Governor and Captain General for approval to start the work, to request the collaboration of the Commander of Engineers, and to use the prisoners from La Puntilla and convicts once more ${ }^{7}$. Nevertheless, a lack of funds would force a temporary suspension of the works the following July, when the previously mentioned prisoners were in charge of cleaning the rubble and land ${ }^{8}$.

The minutes of the Cabildo, before and after the beginning of the general plan to repair streets in 1832, do not reflect important advances in paving and reveal the concern of several councilmen about the deplorable state of some of the city's streets. These mainly included several that ran from East to West, such as that of San Francisco, due to "the Holy Week processions"'; that of Sol, due to the "marshes formed in rainy weather"10; that of San Sebastián, which we will refer to later when we talk about the problem caused by accumulated garbage and the obstruction of drainage pipes ${ }^{11}$; or the alley that joined this last street with the Plaza de Santiago, due to the damage to the foundations of estates caused by rains ${ }^{12}$.

According to María Ángeles Castro, in the early 1830s most streets of San Juan were cobbled, although many -including the main square- were clearly neglected as a result of sinkholes caused by frequent tropical rains (Castro, 1980, p. 142). At the cabildo session of May 10, 1830, caballero regidor (alderman) Don Santiago de Córdoba presented this matter, agreeing that the most damaged streets should be repaired "with what the Real Hacienda (Royal Treasury) provides monthly"13.

Two years later, in 1832, a new plan for street repairs would be drawn up, implemented in the following years, with slabs from the Canary Islands and pebbles (chinos) surrounding the central drainage, and sidewalks lined with bricks on the edge (Castro, 1980, p. 142). Thus, at the cabildo session held on February 13th that year, it was reported that a verbal contract had been signed the previous year, involving one hundred tons of chinos for the paving of the city ${ }^{14}$. A few days later, at the February 20th session, it was agreed that the caballero regidor would walk the streets with the alarife de albañilería (bricklayer) to report on the necessary repairs for "the repair that the Governor has in mind" 15 . Once the inspection was carried out, it was determined that "any restructuring undertaken would be very expensive and would require a stockpile of materials, which would not be less than ten to three thousand pesos", while highlighting the "state of deterioration" in which all the sidewalks and centers were in $^{16}$.

At the cabildo session on March 29th of the same year, several points on this matter were agreed upon, including the appointment of a deputation to manage it, inviting the public "to put forward proposals for the stocks of slabs and chinos that will be needed for the layout of city streets", the appointment "of an honest neighbour" to collect and administer funds and the trust in the Governor and Captain General, "due to whose zeal and efficiency the corporation believes it is superfluous to recommend this great work because it already has so many repeated testimonies to the interest that everything that H. E. yields is for the good of the country"17.

A month later, in the session of April 30th, the deputation named at that cabildo stated that they had not closed the contract for the slabs from the Canary Islands with Don Gregorio Medina, "from the trade of Ponce", because they were waiting for mail from Havana to arrive, which was bringing some slab samples from Vizcaya ${ }^{18}$. While waiting for the paving work to begin, the cabildo agreed that following June that "the holes in the streets would be covered with gravel", a poor quality stone, in order "to avoid falls during the processions of St. John and St. Peter's Day"19. Also, on the occasion of the Real Sello ceremony, the cabildo approved in July the construction of trenches from a section of San Justo Street, due to its "extremely deteriorated" state ${ }^{20}$.

Through an oficio (communication) on August 28th of the same year, Miguel de la Torre employed a tax, intended for the Coliseum, for the paving work ${ }^{21}$. Shortly afterwards, and following what was agreed the previous March, a depositario de calles (paving depositary) was appointed at the cabildo on September 3 and soon after, the contract for the purchase of Vizcaya slabs for the paving was approved ${ }^{22}$, which would not have "any right of introduction", a fact that would lead the Ayuntamiento, at the session held on October 15th, to give "the most expressive thanks" to De la Torre "for the great part" he had taken "in this interesting and useful project" 23 .

The news of the arrival of the Vizcaya slabs at port appears in the minutes of the cabildo session held on August 4,1834 , and it was agreed that the committee would begin to "implement" the articles of the aforementioned minutes dated March 29, $1831^{24}$. Thus, on the first of December of that year, the members of the deputation in charge of the street paving stated that they had appointed Don Manuel Milano as the overseer of the two blocks that were to be repaired on behalf of the fund, with the allocation of six reales a day on working days ${ }^{25}$. Likewise, at the cabildo session on January 15, 1835, it was reported that the paving work would begin the next day ${ }^{26}$.

In the meantime, the heavy rain continued to cause "considerable damage to the paving". The most affected streets in November 1834 were San Justo and the one that 
went up from Plaza de Santiago to San Sebastián. To alleviate this situation temporarily, at a cabildo session on November 17, as usual, the use of the gravel taken from the quarry was approved, "which would be better fixed and firm than laying dirt if it was well trodden on with heavy footsteps" 27 .

In March 1835 a contract was approved with Don Juan Nepomuceno Bello to purchase small slabs from the Canary Islands. By then, new paving had already been completed on two blocks. The fact that the artillery and fortification carts passed along these streets was a cause for concern among the representatives of the street sector, since they were "causing considerable damage to the recently laid floor". Therefore, they requested, at a cabildo session on March 23, that the mentioned carts transit through the enclosures of the wall and along the streets "where the paving has not yet begun"28.

By September of that year, there were already six cuadras enlozadas y enchinadas (blocks paved with slabs and pebbles), and among the proposals for their maintenance, the Ayuntamiento approved the one made by $c a$ ballero regidor Fernández, which consisted of each neighbor monitoring "the maintenance of the front of each of their houses [...] with the explicit duty of replacing what may be missing of one or another item, or to do so at their own expense in the case of omission" ${ }^{29}$. In this regard, we find the example of Manuel Andino, who, after the deterioration of the enchinado caused by water dripping from his house's pipes, had to take responsibility for its repair ${ }^{30}$.

During the last year of De la Torre's government, specifically at the cabildo held on February 29th 1836, the Mayor suggested that a proposal be submitted to H.E. the President for the house numbering and street signage, according to which each neighbor would have to pay the corresponding amount "at the same time the number plate was placed on their house" ${ }^{\prime 31}$. After its approval, at the $c a$ bildo session, which took place on November 3, 1836, the Mayor-President informed that the number plate manufacturer, who designated the street names and house numbers, had finished his work, and that he had to proceed to "place them". In order to do so, they had to appoint a deputy $^{32}$. At the cabildo session on November 23rd, in addition to the reading of the oficio dated November 21st -by which Miguel de la Torre considered himself informed of this matter-, the Mayor-President exposed the "unpleasant accident that happened while fixing the street name plate at the house of Doña Josefa Gorrity", in which "indecent expressions were made to this Corporation and its members" 33 . This event is a clear example of the people's discontent and opposition to one of the measures approved by the authorities, a situation that, as we have seen, was also commonplace in the cases that were chosen to contextualize what happened in the city of San Juan.

As for the state of the paving works, we know, from cabildo minutes such as those of the session held on April 25 th of that year, that the stones removed from the streets being paved were later used for alley sidewalks ${ }^{34}$. We also know that at the beginning of the following August, the paving and cobbling of the area between Tanca Alley and Santiago Plaza, in the eastern part of the walled area, had been completed ${ }^{35}$. Likewise, the minutes reflect the arrival at port of slab shipments for paving, as in that of September 27, 1836, regarding one of 1,665 slabs arriving on a French brig, which was acknowledged by the masonry master builder ${ }^{36}$. The lack of surveillance would cause, more than once, the disappearance of part of the cargo or the damage of some of it, leading the Ayuntamiento to look for a safe place to store $i^{37}$.

After the end of Miguel de la Torre's government, the scheduled paving works and the process of numbering houses and marking streets continued. As mentioned in the minutes of the cabildo session held on March 8, 1837, at that time "the houses in the alleys had yet to be numbered"38. On the other hand, his successor, Governor Miguel López de Baños, would enact his corresponding Bando in 1838, in which, among other things, he would demand that the inhabitants of the capital and other important towns on the island paved their sidewalks with stones or bricks and kept the rest of the streets well cobbled, in a manner that was beneficial for the movement of water (Castro, 1984, p. 23). Indeed, in that same year, the Paseo de Puerto de Tierra would be built in San Juan, a recreational area outside the city walls designed by engineer Manuel Sicardó (Sepúlveda Rivera, 1989, p. 219). Significant places of the urban fabric, such as the Plaza Mayor and the Cathedral, would still take a few years to be paved. The former would be paved during the $1840 \mathrm{~s}$ with slabs from the Canary Islands and river chinos, and in the case of the latter, it would take until the second half of the century (Sepúlveda Rivera, 1989, pp. 270 and 292).

\section{LIGHTING}

As far as the lighting of streets and squares is concerned, at the beginning of the 1820s, at the initiative of the governor, Brigadier Juan Vasco y Pascual, it was arranged that the streets and squares of the city of San Juan be lit by lanterns lighted with olive oil and hanging from ropes tied from one end to the other. "A tribute of a penny for each pound of bread" was approved for its maintenance, which was taken care of by a series of despabiladores or laborers with a ladder, who went along the streets cleaning the wicks of the streetlamps. This event, according to Adolfo de Hostos, coincided with the arrival of Spanish refugees from Venezuela's War of Independence, who brought new ideas that influenced certain modifications in the system, which we will comment on later (Hostos, 1948, pp. 482-483).

Regarding the 1820 s, complaints about the malfunctioning of the city's lighting system were continuous and widespread. According to the minutes of the cabildo, this was due to the poor management of the lighting sector by its tenant, Don Manuel Saviñon. Thus, as a result of Hurricane Santa Ana in 1825, which hit Puerto Rico with a violence never seen before on the island (Schwartz, 2018, p. 146), there was significant damage to San Juan's light- 
ing system. Although, in the cabildo session held at the beginning of August, the aforementioned tenant stated that he had "all the smart people in the business" working on its speedy repair ${ }^{39}$, the truth is that by the middle of the following October, the Alcalde $2^{\circ}$ exposed the flaws that were still observed in the lighting system in spite of the repeated requests made to the aforementioned tenant, so it was agreed to summon him so as to warn him of the imposition of a possible penalty under the terms of the auction $^{40}$.

Years later, there were new complaints against the same tenant, and the cabildo agreed to fine him with 100 pesos in July 1828 for not complying with his contract, after detecting persistent faults in the lighting during the eve and night of San Pedro "and in most of them". Soon after, Saviñon told the Cabildo that 25 lanterns were found broken on the Calle de la Carnicería (Street of the Butcher's Shop) and in other parts of the city. One of the mayors warned him that "the breaking of lanterns that he claims is not a fair reason to not have lighting, as the tenant must have precisely spare lanterns in a warehouse" ${ }^{41}$.

Complaints about the poor state of the lighting continued in early February of the next year, due to the "public and notorious" abandonment by the auctioneer of this sector "in the course of his duties". Furthermore, at the cabildo session held on February 9, the Trustee stated that Sabiñon had the oil warehouse "on one of the city's public streets, and that the residents could not bear the stench of the aforementioned warehouse", and therefore requested that it be moved from San Cristóbal Street "to the leeward side of the city" 42 . Finally, the physicians in charge of inspecting this matter recommended the aforementioned relocation at the cabildo session held on the following March 23, due to the danger posed to public health by the "combustible material" it contained, in the event of a fire ${ }^{43}$.

The issue of the lighting's deteriorated state was to be discussed again at the cabildo session on August 11 of that year, when the Police judge emphasized the fact that the city's lighting was "in the greatest neglect" as some davits and many street lights were missing and some were turned off "just after they were turned on". All this gave rise to a neighbourhood complaint, which blamed this situation on both the auctioneer and the Ayuntamiento itself. Therefore, it was agreed to fine the auctioneer of the lighting sector, Sabiñon, with two hundred pesos and give him a period of eight days to replace the missing davits and lanterns ${ }^{44}$. The lighting's bad condition would also get worse at certain times as a result of the heavy rain and strong winds, which in May 1830 caused "darkness by putting out the lanterns" 45 .

As it happened in other Caribbean and American cities, it was precisely in San Juan in the 1830s where there was a proposal to incorporate the advances and changes in lighting that were being implemented in some European and North American cities. First came the addition of gas lanterns and then, from 1855 , of oil as an illuminant (Hostos, 1948, pp. 482-483). In relation to the first kind, in the session of the cabildo held on April 29, 1833, an oficio containing a proposal by D. José Martínez Días was presented for the auction of San Juan's lighting, "working on gas", for six years" 46 . This matter would be discussed again in the session dated May 20, 1833, and the Trustee explained that the lack of funds did not allow "for the proposals of Martinez unless he took charge of the sector for the same amount as it was auctioned off for". Also, at that cabildo and at the one on June 3, they referred to a file, which had been prepared with a foreigner - D. Guillermo Wedlon, a resident of Naguabo - for the sale of the lighting "with hydrogen gas", requested by the cabildo to De la Torre in order to "further illustrate the matter" 47 .

While this was being discussed, the lighting tenant, Don Manuel González, complained to the cabildo about "the continuous pressure from mayors due to the lack of street lighting", stating that improving it was beyond his reach, "since he tries his best to provide good oil and wicks". In his opinion, the problem lay in "the poorly built lanterns" ${ }^{\prime 48}$.

The matter related to gas lighting would be taken up again in the session of the cabildo held on September 23rd 1833, when the Alcalde $2^{\circ}$ explained that "in the Court of Madrid and other locations of the Peninsula" they had just established "a lighting system even more advantageous in its scope and equitable than those known up to that day", which due to its advantages should be "taken into consideration". On October 15th, the Alcalde $2^{\circ}$ delivered another presentation to the cabildo about "the lighting supplied in Madrid", detailing "its improvement and economy through auctioning" in a meticulous way $^{49}$.

Three years later, during the last year of Miguel de la Torre's term of office, complaints about the poor lighting service provided to the city of San Juan are still registered in minutes, such as that of the cabildo session held on August 9, 1836. In it, the Ayuntamiento would determine the total auction of the sector, considering it more beneficial than a partial auction, which would only include "the lanterns, equipment and installation costs" ${ }^{50}$.

A single bidder would appear at this auction, Manuel Gonzalez as mentioned above, who demanded ninety pesos for each streetlamp of the eighty that constituted the city lighting, plus four hundred pesos for servicing the aforesaid sector. This led the Mayor to suspend the file created for this cause and the Ayuntamiento to agree to request "the merchants of this square, if any of them wants to take over the company, to only take charge of the streetlights in accordance with the proposals established and approved by H.E. the President" 51 .

At the cabildo session on September 13 that same year, the proposal presented by Don Juan Masson would be approved, in which he requested that "he be given the lantern with which the new lighting system would be established in this capital", in order to send it to the United States "and be able to propose, with certainty, the easiest way of organizing this interesting sector to the corporation". To this end he would also request "one of the lanterns used in those countries with the price information of both" 52 . 


\section{CLEANING AND COLLECTION OF GARBAGE}

María de los Ángeles Castro analyzed the issue of cleaning the streets and squares of San Juan in the Bandos Policia y Buen Gobierno. In this sense, she highlights how that of Juan Dabán y Noguera of 1783 and that of Gonzalo Aróstegui y Herrera of 1821, made each neighbour responsible for the cleaning of the front of their own houses. Also, that of Miguel Ángel de Ustáriz of 1789 established that this obligation was daily and concerned the whole neighbourhood. Similarly, the aforementioned Bando of Aróstegui y Herrera and those of Miguel de la Torre from 1824 and 1832, stipulated that every Saturday the executing minister would sweep the fronts that had not been cleaned "on behalf of the omitted residents". She also refers to other articles related to health and hygiene, regarding the dumping of sewage on streets and sidewalks, as well as the deposit and collection of waste (Castro, 1984, pp. 22-24).

We find testimonies from the early 1820 s such as that of Joel R. Poinsett, who, during his visit to the city in September 1822, was pleasantly surprised by how clean and well built San Juan was, attributing its cleanliness "to the washing of rain, so frequent in this weather" and to "the excellent police regulations and the righteous enforcement of ordinances" (Castro, 1980, pp. 140-141). However, the minutes of the Cabildo of November 4, 1823 reflect a concern for "the poor cleanliness" resulting mainly from the discharge of sewage, which caused bad odours and risks to public health ${ }^{53}$.

In order to avoid this problem, at the cabildo session held on March 23, 1829, it was agreed, with the approval of all the members, to submit an oficio to the Governor and Captain General on the need to approve a sewerage project for the town ${ }^{54}$. This matter would be discussed once more at the cabildo session held the following 4th of May, in which the Trustee proposed seven taxes so that the Ayuntamiento could choose those it considered appropriate. It was also agreed to return the file to "H.E. the Governor and Captain General so that H.E. may add the work budget and street plan mentioned in the report of the Commander of Engineers, in order to decide, in his opinion, about the taxes within the appropriate basis and order" 55 . Miguel de la Torre's reply would arrive in a few days, with an oficio on the 11th, in which he stated that the corporation would choose the method it preferred for the preparation of the plan, profiles and budget. The $c a$ bildo would agree, in the session held on May 18, to entrust the work to Agustín Centero, master builder of Royal Fortification Works ${ }^{56}$.

One of the streets that caused the most trouble in this regard was the caño de San Sebastián (pipe of Saint Sebastian), due to the fact that "the waters are not flowing as they should because the pipe is clogged with garbage and dirt". As the Alcalde $1^{\circ}$ (First Mayor) explained at the $c a$ bildo session held on August 11, 1829, he had personally identified "the mud produced by the waters at that spot, as a result of the complaints filed by the neighbours", noting that "in an extension of about twenty rods along the street, there was a bog half a rod deep, reaching at least the entire width of the street, whose clogging, especially in the current season, can be extremely harmful" to public health. As a consequence, the Ayuntamiento would take this matter to the Governor and Captain General so that he would agree on the pipe's cleaning with the Commander of Engineers of the square ${ }^{57}$.

Both the neighbourhood and the waste export contractor would be held responsible for the accumulation of garbage in certain parts of the city because the latter did not comply with his assigned responsibilities, according to the Commander of Engineers at the cabildo session on October $18,1830^{58}$. In this sense, Miguel de la Torre would inform, at the cabildo session of January 30, 1832, of the damage that was caused to the port by the garbage the neighbours threw into the streets when it rained, according to the Navy Commander ${ }^{59}$.

The file on the sewers would be taken up again at the cabildo session held on November 5, 1832, as it was thought that adding it to the one being processed at that time for the paving of the city streets could be useful ${ }^{60}$. However, in August 1834 this project was still pending, so at the session on August 18 the master builder of Royal Fortification Works was reminded to submit the required plan as soon as possible ${ }^{61}$. In fact, a little after the end of Miguel de la Torre's government and when the paving works were quite advanced, the Trustee would take up this idea again at the cabildo session of February 1, 1837, asking the corporation for the paving contract "to be held, if possible, with sewerage, for the sake of the health and the utmost cleanliness of the population" 62 .

The problem of the accumulation of waste and debris due to the obstruction of pipes would be a recurring theme during these years, as a result of complaints like the one made by the Commander of Engineers about the caño de San Sebastián, transcribed by Miguel de la Torre at the $c a$ bildo session held on the 30th of September 1834. In response to this situation, the cabildo would arrange for the cleaning of the aforesaid pipe and the collection of the rubble that was harming the passage of the wall ${ }^{63}$. Regarding the dirt on the streets, caballero regidor Don Esteban Fernández, at the cabildo session of February 22, 1835, held the neighbours responsible -for the lack of fines such as that of two reales which had previously been applied to those who did not sweep on the designated days- as well as the garbage collectors -for loading carts too much "in order to finish soon" and for dropping "half of it on the streets", " thus leaving a street that had just been swept in a worse state than the one it was in beforehand". He also refers to the continuous traffic of animals on the streets, infecting these with "urine and manure, so harmful to public health" ${ }^{64}$. Later, in September of the same year and upon the proposal of caballero regidor Fernández, the Ayuntamiento approved entrusting neighbourhood mayors with the task of monitoring cleanliness and hygiene, "using the constraints contained in the Bando general de Policia"

In extraordinary situations, like the one experienced with the cholera epidemic that affected several places in North America and islands such as Cuba in 1833, the $c a-$ 
bildo would approve an increase in the allocation of the waste collection contractor, so that he would remove the garbage twice a week, for "being the garbage that is removed once a week" - very harmful in those circumstances -, an increase in the number of labourers, and the use of "four medium sized lightweight carts so that they do not damage the paving" 66 .

\section{CONCLUDING THOUGHTS}

Upon analysis of the different aspects selected as the object of study in this research, we can conclude that significant projects were initiated during the government of Miguel de la Torre in Puerto Rico, which contributed to the transformation and improvement of the infrastructure of the city of San Juan. On the one hand, the paving works, although they were not completed at the end of his term, were quite advanced by the beginning of 1837 . This allowed the city to carry out a project that others such as Madrid and Mexico had resolved, albeit with limitations, throughout the 1760s and 1770s. San Juan, like Havana, would not achieve this until the second third of the 19th century, as different factors in both delayed the execution of the works planned for this purpose. Another initiative promoted during De la Torre's government, which was advanced but unfinished by the end of his administration, was the house numbering and street signage. To this extent as well as the previous one, his close collaboration, as president of the Ayuntamiento, with the rest of the members of this institution has been demonstrated.

Among the projects dealt with during his government that were related to the management and transformation of San Juan's urban spaces, there were also those related to the substitution of oil for gas in the city lighting and the integration of a sewage system. In both cases, there were proposals for their implementation that were materialized a few years later, similar to what happened in other cities of the period. In fact, the lighting system was still deficient at the end of his government and the measures approved for the improvement of street cleaning, landfill sites and drainage of pipes blocked by the accumulation of garbage, did not yield the expected results, partly due to the lack of collaboration from the neighbourhood in their fulfilment In spite of this, we can conclude that, during the first half of the 19th century, and more specifically during Miguel de la Torre's government, bases were laid and actions were developed that contributed to a partial transformation of the urban space of Puerto Rico's capital, with significant advances in terms of infrastructure.

\section{ACKNOWLEDMENTS}

This research is part of the projects: Connected Worlds: The Caribbean, Origin of Modern World. This project has received funding from the European Union's Horizon 2020 research and innovation programme under the Marie Sklodowska Curie grant agreement No 823846. El orden y sus desafios en el Circuncaribe hispano, 17911960 (RTI2018-094305-B-100).

\section{NOTES}

1 It is also worth mentioning other studies that have worked on specific aspects of the city of San Juan during the 19th century, concerning urban space and charity (Rivera Rivera, 1992), (Rivera Rivera, 1995), (Martínez Vergne, 1999), (Matos Rodríguez, 1999) or public health (Camuñas Madera, 1992), (Lynn Crowe, 2012) and (Sifres Fernández, 2015).

2 As a result, during the first decades of the 19th century, Puerto Rico experienced significant population growth. Between 1827 and 1834 alone, Puerto Rico's population, according to official statistics, increased by about 60,000 inhabitants, going from nearly 300,000 to almost 360,000 during that period (Navarro García, 1991, p. 19). As far as the city of San Juan is concerned, it went from 8,907 inhabitants in 1816 , to 11,484 in 1827 and 13,000 in 1845 (De Hostos, 1981, p. 21) (Sepúlveda Rivera, 1989 , p. 162).

3 An example, in this respect, is the letter in which the ecclesiastical Cabildo requested De la Torre, at the end of his mandate, to work on improving the Cathedral, in which the following was mentioned: "everything, Your Excellency, prospers, is encouraged and improved in the provincial capital, thanks to the tireless zeal of the Captains General and very especially to the prodigious activity and genius of Your Excellency: the government buildings, the teaching of youth, the streets, the order in establishments, the internal economic systems in administrative bodies, the Security and ornamentation Police, the lighting, the theatre, the dock, the barracks, the arsenal, the avenue; everything rises, is elevated, and tends to be enhanced and perfected; and it is not possible that in this cumulus of positive improvements that beautify the Capital and lift it to the height of contemporary civilization, the urgent need of the church should go unnoticed and remain stationary in disproportionate delay". Letter from the ecclesiastical cabildo to the governor of Puerto Rico (Castro, 1980, pp. 410-411).

4 Archivo General de Puerto Rico, San Juan [AGPR], Fondos documentales municipales, Serie San Juan, Subserie Actas y Acuerdos del Ayuntamiento, 1822-1823, box 10a , 54 B, page 30 .

5 AGPR, Fondos documentales municipales ..., 1822-1823, box $10^{\mathrm{a}}$, page 2; Fondos documentales municipales ..., 1825-28, box 11, pages 43, 44, 141; Fondos documentales municipales ..., $1828-30$, box 11 , page 64 .

6 AGPR, Fondos documentales municipales ..., 1822-1823, box $10^{\mathrm{a}}$, pages 36 and 37 .

7 AGPR, Fondos documentales municipales ..., 1823-25, box 11, pages 56-.57.

8 AGPR, Fondos documentales municipales ..., 1823-25, box 11, page 100.

9 AGPR, Fondos documentales municipales ..., 1825-28, box 11, pages 201 and 202.

10 AGPR, Fondos documentales municipales ..., 1828-30, box 11, page 31 .

11 AGPR, Fondos documentales municipales ..., 1828-30, box 11, page 44 .

12 AGPR, Fondos documentales municipales ..., 1830-31, box 12, pages 66 and 67 .

13 AGPR, Fondos documentales municipales ..., 1828-30, box 11, page 134 .

14 AGPR, Fondos documentales municipales ..., 1832-33, box 12, page 18.

15 AGPR, Fondos documentales municipales ..., 1832-33, box 12, page 21 .

16 "cualquier recomposición que se emprendiere sería costosísima y necesitaría un acopio de materiales, cuyo importe no bajaría de diez a tres mil pesos [...] estado de deterioro". AGPR, Fondos documentales municipales ..., 1832-33, box 12, page 27 .

17 "a hacer proposiciones para los acopios de las losas y los chinos que se han de necesitar para la composición de las calles de toda la ciudad $[\ldots]$ de un vecino honrado $[. .$.$] "a cuyo celo y efi-$ cacia cree superfluo la corporación recomendar esta grande obra por tener ya tantos y tan repetidos testimonios al interés 
que S. E. se toma en todo lo que cede en bien del País". AGPR, Fondos documentales municipales ..., 1832-33, box 12, pages 30-33.

18 AGPR, Fondos documentales municipales ..., 1832-33, box 12 page 36 .

19 "los hoyos de las calles con zahorra [...] de evitar caídas en las carreras de la procesión del día de San Juan y San Pedro". AGPR, Fondos documentales municipales ..., 1832-33, box 12, page 51 .

20 AGPR, Fondos documentales municipales ..., 1832-33, box 12 , page 59.

21 AGPR, Fondos documentales municipales ..., 1834-35, box 12, page 115 .

22 AGPR, Fondos documentales municipales ..., 1832-33, box 12 pages 79-87.

23 "ningún derecho de introducción [...] las más expresivas gracias [...] por la gran parte [...] en este interesante y útil proyecto". AGPR, Fondos documentales municipales ..., 1832-33, box 12 , pages 90-91.

24 AGPR, Fondos documentales municipales ..., 1834-35, box 12 , page 67.

25 AGPR, Fondos documentales municipales ..., 1834-35, box 12 , page 111 .

26 AGPR, Fondos documentales municipales ..., 1834-35, box 12 , pages $115-116$.

27 "detrimentos de consideración en el empedrado", "que bien pisada con pisones se aseguraría y afirmaría mejor que echar tierra". AGPR, Fondos documentales municipales ..., 1834-35, box 12, page 107 .

28 "causando notable perjuicio al piso tan recientemente puesto", "en que no se halle empezado el trabajo del empedrado" AGPR, Fondos documentales municipales ..., 1834-35, box 12, pages $153,164-166$.

29 "por la conservación del frente de sus respectivas casas $[\ldots]$ con la obligación expresa de que repongan lo que faltase de uno u otro artículo o haciéndolo a su costa en caso de omisión". AGPR, Fondos documentales municipales ..., 1834-35, box 12 , pages 217-219.

30 AGPR, Fondos documentales municipales ..., 1836-37, box 13 pages $150-151$

31 AGPR, Fondos documentales municipales ..., 1836-37, box 13, pages 14-15.

32 AGPR, Fondos documentales municipales ..., 1836-37, box 13 , pages $129-130$

33 "accidente desagradable ocurrido al tiempo de fijar la tablilla que denominaba la calle, en la casa de doña Josefa Gorrity [...] mediaron expresiones indecorosas a esta Corporación y sus miembros". AGPR, Fondos documentales municipales ..., 1836-37, box 13, pages 136 and 139

34 AGPR, Fondos documentales municipales ..., 1836-37, box 13, page 26.

35 AGPR, Fondos documentales municipales ..., 1836-37, box 13, page 87 .

36 AGPR, Fondos documentales municipales ..., 1836-37, box 13, page 107.

37 AGPR, Fondos documentales municipales ..., 1836-37, box 13 , pages $157-158$

38 AGPR, Fondos documentales municipales ..., 1836-37, box 13, page 223.

39 AGPR, Fondos documentales municipales ..., 1825-28, box 11 , page 182 .

40 AGPR, Fondos documentales municipales ..., 1825-28, box 11 , page 1 .

41 "y en casi la mayor parte de ellas", "el rompimiento de faroles que manifiesta no es motivo justo para tener sin alumbrado, pues el arrendatario debe tener precisamente en un almacén repuestos de faroles". AGPR, Fondos documentales municipales $\ldots, 1825-28$, box 11 , pages $227,228,231,232$

42 "público y notorio [...] en el lucimiento de su cargo", "en una de las calles públicas de esta ciudad, no pudiendo los vecinos sufrir la fetidez que expele dicho almacén [...] a sotavento de la ciudad". AGPR, Fondos documentales municipales ..., 182830 , box 11 , pages $37,38,47$.

43 AGPR, Fondos documentales municipales..., 1828-30, box 11, pages 47 y 48 .

44 AGPR, Fondos documentales municipales ..., 1828-30, box 11, pages 77 and 78 .

45 AGPR, Fondos documentales municipales ..., 1828-30, box 11, page 137.

46 AGPR, Fondos documentales municipales ..., 1832-33, box 12 , page 144

47 "entrar por las proposiciones de Martínez a menos que este se hiciese cargo del ramo por la misma suma en que está rematado", "con gas hidrógena [...] ilustrar más la materia". AGPR, Fondos documentales municipales ..., 1832-33, box 12, pages $149-153$

48 "los continuos apremios que le hacen los señores alcaldes por la falta de luz de los faroles [...] pues se esmera lo posible poniendo buen aceite y mecha", "la mala construcción de los faroles". AGPR, Fondos documentales municipales ..., 1832-33, box 12 , pages 161-162.

49 "en la Corte de Madrid y otros puntos de la Península [...] un alumbrado aún más ventajoso en su alcance y equitativo que los conocidos hasta el día [...] tomarse en consideración". "el alumbrado que se sirve en Madrid [...] la mejora y economía al remate". AGPR, Fondos documentales municipales ..., 1832-33, box 12, pages 193-194, 199-200

50 AGPR, Fondos documentales municipales ..., 1836-37, box 13, pages $85-86$

51 "a los comerciantes de esta plaza si alguno quiere hacerse cargo de la empresa de sólo hacer servir los faroles con arreglo a las proposiciones establecidas y aprobadas por el Excmo. Sr. Presidente". AGPR, Fondos documentales municipales ..., 1836-37, box 13 , page 97

52 "se le franquease el farol con que se quiere establecer el nuevo alumbrado en esta capital [...] y poder con certeza proponer a la corporación el medio más fácil de organizar este interesante ramo", "uno de los faroles de los que se usan en aquellos países con noticia del importe de ambos". AGPR, Fondos documentales municipales ..., 1836-37, box 13, page 102

53 "al arrastre de las lluvias, tan frecuentes en este clima [...] que la reglamentación de policía es excelente y que se hacen cumplir con rectitud las ordenanzas", "el poco aseo". AGPR, Fondos documentales municipales ..., 1823-25, box 11, page 15 .

54 AGPR, Fondos documentales municipales ..., 1828-30, box 11, page 48 .

55 "E. Sr. Gobernador y Capitán General a fin de que S. E. se sirva disponer se le agreguen el presupuesto de la obra y el plano de las calles de que habla el informe del Sr. Comandante de Ingenieros, para en su vista determinar acerca de la elección de los arbitrios con el fundamento y por el orden que corresponde". AGPR, Fondos documentales municipales ..., 1828-30, box 11, pages 55 and 56.

56 AGPR, Fondos documentales municipales ..., 1828-30, box 11, page 59 .

57 "las aguas no corren como debían por estar tapado el caño con basura y tierra", "el lodazal que producen las aguas en aquel punto, a consecuencia de las quejas interpuestas por los vecinos [...] en una extensión como de veinte varas a lo largo de la calle había un fangal de media vara de profundidad, a lo menos que cogía todo lo ancho de esta, cuyo empozamiento especialmente en la actual estación puede llegar a ser perjudicialísimo" AGPR, Fondos documentales municipales ..., 1828-30, box 11, page 77.

58 AGPR, Fondos documentales municipales ..., 1830-31, box 12, page 9.

59 AGPR, Fondos documentales municipales ..., 1832-33, box 12 , page 15 .

60 AGPR, Fondos documentales municipales ..., 1832-33, box 12 page 97.

61 AGPR, Fondos documentales municipales ..., 1834-35, box 12 , pages $70-71$. 
62 "se celebre si es posible con alcantarillas, por el bien que resulta a la salubridad y al más completo aseo de la población". AGPR, Fondos documentales municipales ..., 1836-37, box 13, pages 185-186.

63 AGPR, Fondos documentales municipales ..., 1834-35, box 12, pages 93,95 and 96.

64 "para acabar pronto [...] la mitad en las calles [...] así es que una calle acabada de barrer la dejan en peor estado al que estaba", "orín y estiércol, tan perjudicial a la salud pública". AGPR, Fondos documentales municipales ..., 1834-35, box 12, pages 149-150.

65 AGPR, Fondos documentales municipales ..., 1834-35, box 12, page 219 .

66 "ser las basuras que se sacan una vez a la semana", "cuatro carretas medianas de construcción ligera para que no dañe el empedrado". AGPR, Fondos documentales municipales..., 183233, box 12, pages 208, 218.

\section{REFERENCES}

Altagracia Espada, Carlos D. (2013) La utopía del territorio perfectamente gobernado. Miedo y poder en la época de Miguel de la Torre. Puerto Rico 1822-1837. Puerto Rico: Publisher not identified.

Altieri, Gerardo Carlo (2007) Justicia y gobierno. La Audiencia de Puerto Rico (1831-1861). Madrid: Escuela de Estudios Hispano-Americanos - CSIC; San Juan: Academia Puertorriqueña de la Historia.

Amigo Requejo, Ana (2013) "Códigos de la nueva ciudad: alumbrado público y mobiliario urbano en La Habana de Miguel Tacón y Rosique (1834-1838)". Res Mobilis, Oviedo: Universidad de Oviedo, vol. 2, no 2, pp. 3-15. Available at: https://www.unioviedo.es/reunido/index.php/RM/article/view/9950 [Accessed 5 Oct. 2019].

Amigo Requejo, Ana (2014) "El Teatro principal: Ingenieros Militares y especulación en La Habana del siglo XIX". Quiroga, Granada: Universidad de Granada, $n^{\circ}$ 5, enero-junio, pp. 12-27.

Anguita Cantero, Ricardo (1997) Ordenanza y Policía Urbana: los orígenes de la reglamentación edificatoria en España (1750 1900). Granada: Universidad de Granada.

Apaolaza-Llorente, Dorleta (2018) "La Habana ilustrada del siglo XVIII: sus transformaciones urbanas a través de la mirada de los bandos de buen gobierno. Cambiando la imagen de poder". Iberoamérica Social, Revista-red de estudios sociales, España: Asociación Reconocer, $\mathrm{n}^{\mathrm{o}}$ Extra 2, pp. 63-80. Available at: https://iberoamericasocial.com/ojs/index.php/IS/article/ view/285/381 [Accessed 10 Apr. 2019].

Arroyo, Mercedes (2002) "Estrategias empresariales y redes territoriales en dos ciudades españolas, Barcelona y Madrid (18321923)". Historia Contemporánea, Leioa: Universidad del País Vasco, no 24, pp. 137-160. Available at: https://www.ehu.eus/ ojs/index.php/HC/article/view/5962 [Accessed 15 Apr. 2019].

Blanco Esquivias, Beatriz (1998) ;Agua va! La higiene urbana en Madrid (1561-1761). Madrid: Caja Madrid.

Camuñas Madera, Ricardo R. (1992) Epidemias, plagas y marginación: la lucha contra la adversidad en Puerto Rico en los siglos XVIII y XIX. Puerto Rico: Editorial Universidad de América.

Caro Costas, Aida R. (1974) El cabildo o régimen municipal puertorriqueño en el siglo XVIII. San Juan de Puerto Rico: Instituto de Cultura Puertorriqueña, Tomo II.

Castro Arroyo, Ma de los Ángeles (1980) Arquitectura en San Juan de Puerto Rico (siglo XIX). San Juan de Puerto Rico: Editorial Universitaria, Universidad de Puerto Rico.

Castro Arroyo, Ma de los Ángeles (1984) "Los moldes imperiales: ordenamiento urbano en los bandos de policía y buen gobierno". Cuaderno de la Facultad de Humanidades, Puerto Rico: Universidad de Puerto Rico, ${ }^{\circ} 12$, pp. 11-34.

Contreras Padilla, Alejandra (2014) "La noche y la Ciudad de México". Bitácora arquitectura, México: Facultad de Arquitectura de la Universidad Nacional Autónoma de México, $\mathrm{n}^{\circ}$ 28, pp.
44-51. Available at: http://www.revistas.unam.mx/index.php/ bitacora/article/view/56113 [Accessed 10 Jul. 2019].

Cortés Zavala, Ma Teresa (2009-2010) "Los Bandos de Policía y Buen Gobierno en Puerto Rico. El ordenamiento urbano y la protección de la salud y la higiene en el siglo XIX". Op. Cit., Revista del Centro de Investigaciones Históricas, no 19, pp. 107-142.

Cortés Zavala, M ${ }^{\mathrm{a}}$ Teresa (2017) Orden social y salud pública en Puerto Rico, siglo XIX. Una mirada desde la historia cultural. México: Universidad Michoacana de San Nicolás de Hidalgo.

Crowe, Monica L. (2012) Rise of Public Works and Sanitation in San Juan, Puerto Rico, 1765-1823. Florida: Florida International University, Electronic Thesis and Dissertations. Available at: http://digitalcommons.fiu.edu/cgi/viewcontent.cgi?article=1699\&context $=$ etd [Accessed 5 Jun. 2018].

Dávalos, Marcela (1989) De basuras e inmundicias y movimiento. $O$ de cómo se limpiaba la ciudad de México a finales del siglo XVIII. México: Cienfuegos.

Dávalos, Marcela (1997) Basura e Ilustración. La limpieza de la ciudad de México a fines del siglo XVIII. México: Instituto Nacional de Antropología e Historia.

Escobedo Mansilla, Ronald (1995) "El Bando de Buen Gobierno, instrumento de la Ilustración”. In: Memoria del X Congreso del Instituto Internacional de Historia del Derecho Indiano, México: Universidad Nacional Autónoma de México, pp. 473-495.

Espinosa Fernández, José Manuel (2015) Elites y política colonial en los márgenes del imperio. Puerto Rico, 1765-1815. Sevilla: Escuela de Estudios Hispano-Americanos, Universidad del Norte, Oficina del Historiador Oficial de Puerto Rico, Asociación Cultural la otra Andalucía.

Freire-Lista, David Martín (2016) El granito como piedra de construcción en Madrid: durabilidad y puesta en valor. Tesis doctoral dirigida por Rafael Fort González y María Josefa Varas Muriel. Madrid: Universidad Complutense de Madrid, 2016.

García Lázaro, A. (2016) "De empresa de alumbrado a empresa de servicio de energía eléctirca: la CMGLE en la ciudad de México, 1896-1905", In: Letras Históricas, Guadalajara, Universidad de Guadalajara, no 15 , pp. 123-143. Available at: http:// www.scielo.org.mx/scielo.php?script $=$ sci arttext\&pid $=$ S2448$83722016000200123 \& \operatorname{lng}=$ es\&nrm=iso [Accessed 6 feb. 2020].

Gili Ruiz, Rafael (2017) Higiene y alcantarillado en el Madrid del Antiguo Régimen. Tesis doctoral dirigida por el Dr. Virgilio Pinto Crespo. Madrid: Universidad Autónoma de Madrid.

González Vales, Luis (1990) "El Cabildo de San Juan Bautista de Puerto Rico en el siglo XVIII y la defensa de los derechos de los vecinos". Revista Chilena de Historia del Derecho, Santiago de Chile, Universidad de Chile, $n^{\circ} 16$, pp. 205-218. Available at: file://C:/ Users/Usuario/Downloads/24069-1-77677-1-10-20121106.pdf [Accessed 3 Feb. 2019].

González Vales, Luis y Luque, Ma Dolores (coord.) (2012) Historia de Puerto Rico. Madrid: Consejo Superior de Investigaciones Científicas; Aranjuez: Doce Calles, Colección Historia de las Antillas, vol. IV.

Gortari Rabiela, Hira de (2002) "La ciudad de México de finales del siglo XVIII: un diagnóstico desde la Ciencia de la Policía". Historia Contemporánea, Bilbao: Servicio editorial de la Universidad del País Vasco, n 24: pp. 115-135. Available at: https:/www. ehu.eus/ojs/index.php/HC/article/view/5960/5640 [Accessed 22 Apr. 2019].

Hernández, N. (1987) La política económica de Miguel de la Torre, 1823-1837. Tesis doctoral dirigida por el Dr. Gervasio García. Puerto Rico: Universidad de Puerto Rico.

Hernández Franyuti, Regina (1997) Ignacio de Castera, arquitecto y urbanista de la ciudad de México. México: Instituto de Investigaciones Dr. José María Luis Mora.

Hostos, Adolfo de (1948) Ciudad Murada. Ensayo acerca del proceso de la civilización en la ciudad española de San Juan Bautista de Puerto Rico. 1521-1898. La Habana: Editorial Lex.

Hostos, Adolfo de (1957) Crecimiento y desarrollo de la ciudad de San Juan. San Juan: Instituto de Cultura Puertorriqueña. 
Instrucción reservada que el Conde de Revilla Gigedo, dio a su sucesor en el mando, Marqués de Branciforte, sobre el gobierno de este continente en el tiempo que fue su virey (1831) México: Imprenta de la calle de las Escalerillas.

Jiménez Garnica, Ana Ma (2002) “Urbanismo y Salud Pública. El Paseo del Prado madrileño: Un ejemplo de saludable armonía entre la Naturaleza y el Arte en el espacio urbano”. Anales de la Real Academia Nacional de Farmacia, Madrid: Real Academia de Farmacia, $n^{\circ} 4$, pp. 157-205. Available at: http://bibliotecavirtual. ranf.com/es/consulta/registro.do?id=17700 [Accessed 17 Apr. 2018]

Jori, Gerard (2013) "La ciudad como objeto de intervención médica. El desarrollo de la medicina urbana en España durante el siglo XVIII". Scripta Nova, Revista Electrónica de Geografia y Ciencias Sociales, Barcelona: Universidad de Barcelona, vol. XVII, $\mathrm{n}^{\circ}$ 341, 1 de marzo de 2013. Available at: http://www. ub.edu/geocrit/sn/sn-431.htm [Accessed 11 Jun. 2017].

Lalinde Abadía, Jesús (1980) La administración española en el siglo XIX Puertorriqueño. Sevilla: Escuela de Estudios HispanoAmericanos, CSIC.

Madrid Calzada, Rufino Manuel (2007) Vencer la noche: la Sevilla iluminada. Una historia del alumbrado público de Sevilla. Sevilla: Universidad de Sevilla, Secretariado de Publicaciones.

Martínez-Vergne, Teresita (1999) Shaping the Discourse on Space: Charity and Its Wards in Nineteenth-Century San Juan. Austin: University of Texas Press.

Matos Rodríguez, Félix V. (1999) Women and Urban Change in San Juan, Puerto Rico, 1820-1868. Gainesville: University Press of Florida.

Moncada Maya, Omar (2006) "La ciudad de México a finales del siglo XVIII. Una descripción por el ingeniero Miguel Constanzó". Biblio 3W, Revista bibliográfica de Geografía y Ciencias Sociales, Barcelona: Universidad de Barcelona, vol. XI, $\mathrm{n}^{\circ} 692$ Available at: http://www.ub.edu/geocrit/b3w-692.htm\#14 [Accessed 23 Jul. 2018].

Naranjo Orovio, C. (1992) "Iberoamérica independiente 18201850. Los casos de las Antillas Españolas". In: Cerrillos, $\mathrm{M}^{\mathrm{a}}$ Luisa (coord.), Historia Urbana de Iberoamérica. Madrid: Testimonio, tomo III-1, pp.289-304.

Navarro García, Jesús Raúl (1991) Control social y actitudes politicas en Puerto Rico (1823-1837). Sevilla: Excma. Diputación Provincial de Sevilla.

Navarro García, Jesús Raúl (1999) Puerto Rico a la sombra de la independencia continental: fronteras ideológicas y politicas en el Caribe, 1815-1840. San Juan: Centro de Estudios Avanzados de Puerto Rico y el Caribe, Sevilla: Consejo Superior de Investigaciones Científicas.

Ortiz Malave, M. P. (2016) El estado español y su proyecto de modernización del siglo XIX: infraestructura vial en la isla de Puerto Rico durante la gobernación de Miguel de la Torre
(1822-1837). Tesis doctoral dirigida por el Dr. Marcial E. Ocasio Meléndez. San Juan: Centro de Estudios Avanzados de Puerto Rico y el Caribe.

Reguera Rodríguez, Antonio T. (1992) "Urbanismo y medioambiente en la España de la Ilustración. Estudio de varias problemáticas". Polígonos, León: Universidad de León, no 2, pp. 109140.

Rivera Rivera, Antonia (1992) El problema de la vagancia en el Puerto Rico del siglo XIX. Exégesis, Puerto Rico: Universidad de Puerto Rico, año 5, nº 14, pp. 12-19.

Rivera Rivera, Antonia (1995) El Estado español y la beneficencia en el Puerto Rico del siglo XIX. Santo Domingo: El Cuervo Dorado.

Rodríguez, Ma Eugenia (2000) Contaminación e insalubridad en la ciudad de México en el siglo XVIII. México, Facultad de Medicina / UNAM, Serie Monografías de Historia y Filosofía de la Medicina, $n^{\circ} 3$.

Romero, José Luis (1986) Latinoamérica: las ciudades y las ideas. 4th. Ed. Buenos Aires: Siglo XXI Editores.

Sánchez de Tagle, Esteban (1995) "Las monjas ante la remodelación urbana del siglo XVIII", In: Ramos, Manuel (coord.), El monacato femenino en el imperio español (Memoria del Segundo Congreso Internacional). México: Centro de Estudios de Historia de México (CONDUMEX), pp. 149-154.

Sánchez de Tagle, Esteban (1997) Los dueños de la calle. Una historia de la vía pública en la época colonial. México: Departamento del Distrito Federal, Dirección de Estudios Históricos INAH.

Schwartz, Stuart B. (2018) Mar de Tormentas. Una historia de los huracanes en el Gran Caribe desde Colón hasta María, San Juan, Ediciones Callejón.

Sepúlveda Rivera, Anibal (1989) San Juan. Historia ilustrada de su desarrollo urbano. 1508-1898. San Juan: Carimar.

Sica, Paolo (1982) Historia del urbanismo. El siglo XVIII. Madrid: Instituto de Estudios de Administración Local.

Sifres Fernández, Vicent (2015) Poderes, sanidad y marginación: El cólera morbo en la ciudad de San Juan Bautista de Puerto Rico a mediados del siglo XIX. Tesis doctoral dirigida por la Dra. Mayra Rosario Urrutia. Río Piedras: Universidad de Puerto Rico.

Solano, Francisco de (1988) "Ciudad y geoestrategia española en América durante el siglo XVIII". In: La América Española en la época de las Luces. Madrid: Instituto de Cooperación Iberoamericana, pp. 37-57.

Vega Janino, J. (1989) "Las reformas borbónicas y la ciudad americana". In: La Ciudad Hispanoamericana. El Sueño de un Orden. Madrid: Centro de Estudios Históricos de Obras Públicas y Urbanismo CEHOPU, Ministerio de Obras Públicas y Urbanismo, pp. 240-244.

Vivas Maldonado, José Luis (1974) Historia de Puerto Rico. Madrid: Anaya. 